\title{
MENINGKATKAN HASIL BELAJAR MATEMATIKA SISWA DENGAN MENGGUNAKAN MODEL PEMBELAJARAN TEAM ACCELERATED INSTRUCTION (TAI)
}

\author{
Oleh : \\ * Nurpesti \\ SD Negeri 200108 Padangsidimpuan
}

\begin{abstract}
Abstrak
Penelitian ini bertujuan mendeskripsikan penggunaan model pembelajaran Team Accelerated Instruction (TAI) dan peningkatannya terhadap hasil belajar siswa materi pokok keliling dan luas bangun datar di kelas IV SD Negeri 200304 Padangsidimpuan. Penelitian ini merupakan penelitian tindakan kelas dengan tiga siklus yaitu perencanaan, pelaksanaan tindakan, dan refleksi. Subjek penelitian ini yaitu siswa kelas IV SD Negeri 200304 Padangsidimpuan yang berjumlah 24 siswa. Teknik pengumpulan data menggunakan tes dan lembar observasi. Hasil penelitian menunjukkan bahwa: hasil belajar siswa melalui model pembelajaran TAI di kelas IV SD Negeri 200304 Padangsidimpuan meningkat dibuktikan pada siklus I memperoleh persentase sebesar 54\%, pada siklus II 83\%, dari siklus I ke siklus II mengalami peningkatan sebesar 29\%. Kinerja guru melalui model pembelajaran TAI di kelas IV SD Negeri 200304 Padangsidimpuan meningkat dapat dilihat pada persentase observasi responden guru pada siklus I sebesar 67,50\% kategori "Cukup" dan siklus II 82,50\% kategori "Baik", dari siklus I ke siklus II mengalami peningkatan sebesar 15,0\%. Aktivitas belajar siswa melalui model pembelajaran TAI dari siklus I ke siklus II mengalami peningkatan sebesar 48,49\% yang mana persentase observasi aktivitas siswa pada siklus I sebesar 67,19\% kategori "Cukup" dan siklus II 81,25\% kategori "Baik", dari siklus I ke siklus II mengalami peningkatan sebesar 14,06\%.
\end{abstract}

Kata kunci-Model Pembelajaran, Team Accelerated Instruction (TAI), Hasil Belajar, Keliling, Luas Bangun Datar.

\section{PENDAHULUAN}

Matematika merupakan ilmu dasar yang dipelajari manusia selain dari membaca dan menulis. Mampu dalam membaca, menulis serta menguasai ilmu matematika berarti mempunyai harapan untuk mudah dan cepat memahami ilmu pengetahuan yang lain. Kenyataannya, sebagian besar siswa menganggap bahwa matematika adalah suatu pelajaran yang sulit untuk dipahami dan membosankan, sehingga menyebabkan banyak siswa tidak menyukai pelajaran matematika pada akhirnya dapat menjadi salah satu penyebab rendahnya hasil belajar siswa.

Hasil studi awal yang dilakukan peneliti melalui wawancara dan observasi peneliti dengan wali kelas IV di SD Negeri 200304 Padangsidimpuan, siswa beranggapan bahwa pelajaran matematika itu sangat sulit, siswa juga jarang mengerjakan PR saat guru yang bersangkutan memberikan tugas, nilai hasil belajar siswa jarang mencapai KKM $=70$ saat mengerjakan soal-soal dalam kelas dan sebagian siswa jika disuruh bertanya kebanyakan siswa hanya diam dan takut untuk mengungkapkan pendapatnya dan mengakibatkan pembelajaran menjadi membosankan, siswa tidak bersemangat dan kurang bergembira dalam belajar matematika yang menyebabkan hasil belajar matematika siswa rendah di kelas IV SD Negeri 200304 Padangsidimpuan, ketika mengajar guru mata pelajaran matematika kurang menerapkan model pembelajaran yang bervariasi, dan lebih dominan menggunakan metode ceramah, sehingga siswa merasa jenuh dalam proses pembelajaran dan pada akhirnya berdampak pada hasil belajar siswa dapat dilihat pada Tabel 1 .

Tabel 1. Hasil Ujian Tengah Semester Siswa Kelas IV SD Negeri 200304 Padangsidimpuan

\begin{tabular}{|c|c|c|}
\hline Kualifikasi & Jumlah & Persentase (\%) \\
\hline Tuntas & 10 & 42 \\
\hline Tidak Tuntas & 14 & 58 \\
\hline
\end{tabular}


Tabel 1 di atas menunjukkan bahwa persentase siswa yang belum tuntas masih tinggi dibandingkan dengan yang tuntas. Penyebab hasil belajar matematika rendah karena penerapan pembelajaran yang kurang bervariasi, dan kurang mampu menarik perhatian siswa untuk belajar. Untuk itu perlu digunakan model pembelajaran yang bervariasi agar siswa merasa nyaman dan tidak merasa bosan saat belajar serta dapat membantu siswa untuk berbagi ilmu, saling membantu agar mampu meningkatkan hasil belajar siswa.

Salah satu bentuk model pembelajaran yang dianggap dapat memberikan kontribusi yang cocok dalam upaya meningkatkan hasil belajar siswa pada materi keliling dan luas bangun datar adalah TAI. Model ini didesain untuk membantu siswa dalam memperjelas tujuan belajar agar mengetahui makna dari belajar, sehingga siswa tertarik untuk mempelajarinya dan mengetahui manfaatnya pada materi tersebut. Pada umumnya siswa berkeinginan untuk dapat dengan mudah memahami konsep yang di pelajari dalam pembelajaran, dan guru berusaha meningkatkan hasil belajar siswa serta memilih model pembelajaran yang tepat. Menurut Fikrie (2012:17) Model pembelajaran TAI merupakan model pembelajaran yang membentuk kelompok kecil yang heterogen dengan latar belakang cara berfikir yang berbeda untuk saling membantu terhadap siswa lain yang membutuhkan bantuan. Selanjutnya, Handayani (2012:34) melalui hasil penelitian ini menunjukkan bahwa, model pembelajaran TAI (Team Accelerated Instruction) pada siswa kelas IVIII E SMP Negeri 1 Kec. Siman Ponorogo Tahun Pelajaran 2011/2012 mampu meningkatkan hasil belajar siswa.

Model Pembelajaran TAI memiliki kelebihan diantaranya: siswa yang pandai ikut bertanggung jawab membantu yang lemah dalam kelompoknya. Dengan demikian siswa yang pandai dapat mengembangkan kemampuan dan keterampilannya, siswa yang lemah akan terbantu dalam memahami materi pelajaran, tidak ada persaingan antar siswa karena siswa saling bekerjasama untuk menyelesaikan masalah dalam mengatasi cara berpikir yang berbeda, siswa tidak hanya mengharap bantuan dari guru, tetapi siswa juga termotivasi untuk belajar cepat dan akurat pada seluruh materi dan guru setidaknya hanya menggunakan setengah dari waktu mengajarnya sehingga akan lebih mudah dalam pemberian bantuan secara individu.

\section{METODE PENELITIAN}

Jenis penelitian ini adalah Penelitian Tindakan Kelas (PTK). Adapun lokasi penelitian di SD Negeri 200304 Kota Padangsidimpuan pada kelas IV SD dengan jumlah siswa terdiri dari 6 siswa putra dan 14 siswa putri. Pelaksanaan penelitian ini pada Semester I Tahun Pelajaran 2018-2019. Waktu yang ditetapkan ini dipergunakan dalam rangka penelitian awal dan pengambilan data sebagai bahan yang akan diolah untuk mendapatkan jawaban terhadap hipotesis yang ditegakkan sebagai kesimpulan dalam penelitian.

Objek yang diamati dalam penelitian ini adalah hasil belajar siswa dalam pelaksanaan pembelajaran di kelas dengan menggunakan model pembelajaran TAI di kelas IV SD Negeri 200304 Padangsidimpuan. Sedangkan, subjek dalam penelitian ini adalah siswa kelas IV SD Negeri 200304 Padangsidimpuan yang terdiri dari 24 orang dimana laki-laki terdiri dari 13 orang dan perempuan 11 orang. Alasan penulis memilih subjek adalah karena ditemukannya hasil belajar matematika siswa pada materi keliling dan luas bagun datar sangat rendah.

PTK yang direncanakan dengan dua siklus. Masing-masing siklus terdiri dari 4 tahap, yaitu planning (perencanaan), acting (pelaksanaan), observating (pengamatan) dan reflecting (refleksi). Apabila dalam dua siklus indikator keberhasilan belum tercapai maka akan dilanjutkan sampai siklus ketiga. Teknik pengumpulan data yang digunakan dalam penelitian adalah tes dan observasi. Tes untuk mengungkapkan keberhasilan hasil belajar siswa dengan model pembelajaran TAI dalam belajar matematika materi keliling dan luas bangun datar dalam bentuk essay. Sedangkan, lembar observasi digunakan untuk mengamati aktivitas siswa saat pembelajaran dilaksanakan oleh pengamat (Observer) dan kinerja guru melalui model pembelajaran TAI.

Teknik analisis hasil belajar siswa data yang akan dilakukan yakni dengan data hasil pengamatan hasil belajar selama kegiatan pembelajaran dianalisis berdasarkan persentase dengan rumus sebagai berikut:

$\mathrm{PKK}=(\mathrm{J}) / \mathrm{N} \times 100 \%$

Selanjutnya, Aanalisa data hasil belajar menggunakan ketuntasan maksimal (KKM) siswa dengan ketuntasan $\geq 70$ sedangkan data aktivitas siswa diperoleh dari hasil observasi dan analisis menggunakan rumus:

$$
\mathrm{NA}=(\mathrm{JS}) / \mathrm{SM} \times 100 \%
$$

\section{HASIL DAN PEMBAHASAN 3.1. Deskripsi Hasil Siklus I}


ISSN. 2621-9832

JURNAL MathEdu (Mathematic Education Journal) http://journal.ipts.ac.id/index.php/MathEdu

Vol. 4 No. 2 Juli 2021

Siklus I merupakan pembelajaran dengan materi keliling dan luas bangun datar. melalui model pembelajaran TAI mulai diperkenalkan pada siswa dalam pembelajaran untuk melihat hasil peningkatan hasil belajar siswa. Harapannya kemampuan yang diperoleh peserta didik setelah melalui kegiatan belajar mengalami perubahan atau peningkatan yang lebih baik. Menurut Karim (2017:4) Hasil belajar merupakan suatu proses dari seseorang yang berusaha untuk memperoleh suatu bentuk perubahan relatif menetap. Peningkatan kualitas pendidikan dapat dilihat dari meningkatnya hasil belajar atau prestasi belajar yang diperoleh siswa.

Untuk melihat peningkatan hasil belajar siswa menggunakan tes. Hasil studi awal diperoleh nilai rata-rata hasil belajar siswa 57.17, sedangkan dengan menggunakan model pembelajaran TAI pada siklus I diperoleh nilai rata-rata 70.43. Hal ini menunjukkan terjadi peningkatan hasil belajar siswa. Sedangkan, untuk melihat gambaran ketuntasan hasil belajar siswa dapat dilihat pada Gambar 1.

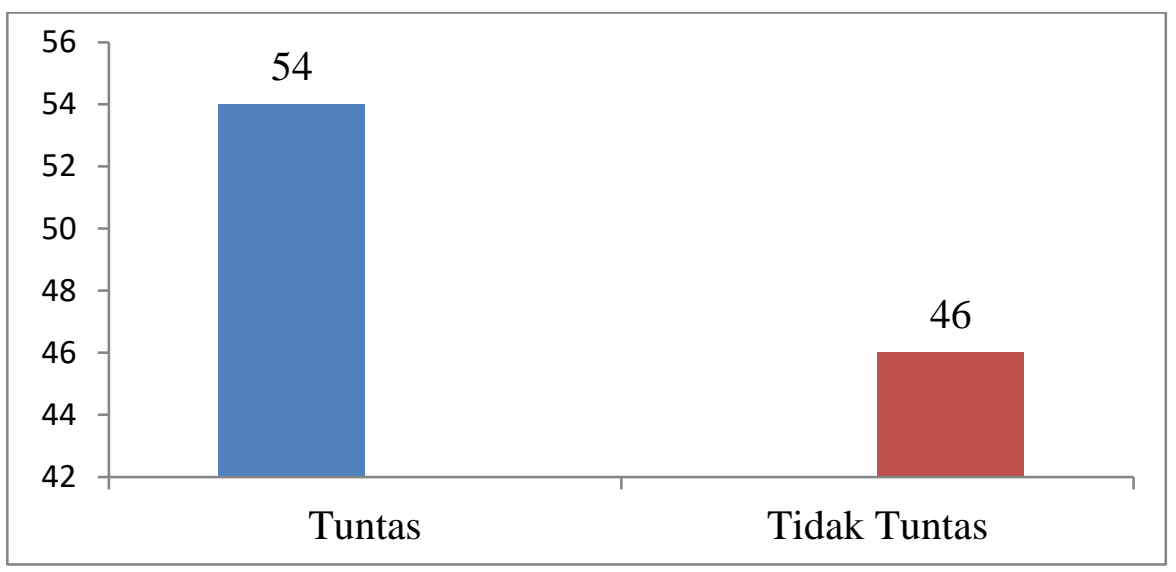

Gambar 1. Deskripsi Ketuntasan Hasil belajar Siswa Siklus I

Dari gambar 1 di atas pada siklus I dapat dilihat hasil tes hasil belajar siswa masih kurang yaitu sebesar 54\% persentase siswa yang tuntas atau hanya 13 orang siswa yang dinyatakan tuntas dan 11 orang atau $46 \%$ dinyatakan tidak tuntas, untuk itu perlu adanya perbaikan dan peningkatan pembelajaran siklus II. Diharapkan pada siklus II hasil yang diperoleh lebih baik lagi dibandingkan dengan siklus I. Selanjutnya, guru PTK bersama peneliti merancang kegiatan yang lebih baik lagi agar memperoleh hasil yang baik sesuai dengan kriteria ketuntasan minimal (KKM) yang telah ditetapkan sekolah yaitu nilai di atas $\geq 75$.

Aktivitas belajar siswa menggunakan model pembelajaran TAI dapat dilihat dengan menggunakan lembar observasi. Hasil penelitian menunjukkan aktivitas belajar siswa menggunakan model pembelajaran TAI dapat dilihat pada Gambar 2.

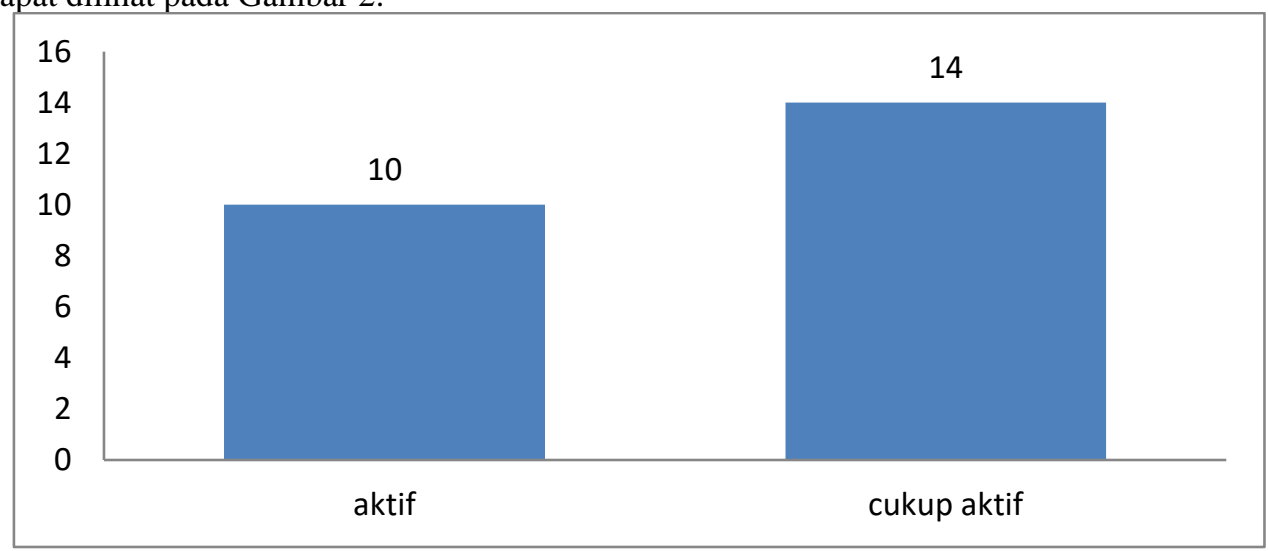

\section{Gambar 2. Deskripsi Aktivitas Belajar Siswa Menggunakan Model Pembelajaran} TAI Siklus I

Berdasarkan Gambar 2 di atas, maka jumlah siswa yang kriteria aktif mengikuti pembelajaran hanya 10 orang dan 14 orang lainnya dengan kriteria cukup aktif, dari hasil yang diperoleh maka perlu perbaikanperbaikan yang dilaksanakan pada siklus selanjutnya. Hasil pengamatan terhadap aktivitas siswa dalam pembelajaran setiap pertemuan selama 2 kali tatap muka dinyatakan dengan persentasi. Hasil tersebut disajikan secara ringkas pada Tabel 2. 
Tabel 2. Observasi Aktivitas Siswa Siklus I

\begin{tabular}{|c|l|c|c|c|}
\hline \multirow{2}{*}{ No Indikator } & \multicolumn{1}{|c|}{ Pertemuan } & \multirow{2}{*}{$\begin{array}{c}\text { Rata- } \\
\text { rata }\end{array}$} \\
\cline { 3 - 5 } & & I & II & \\
\hline 1 & $\begin{array}{l}\text { Antusiasme siswa dalam mengikuti kegiatan } \\
\text { pembelajaran }\end{array}$ & 3 & 3 & 3.0 \\
\hline 2 & Interaksi siswa dengan guru & 2 & 3 & 2.5 \\
\hline 3 & Interaksi siswa dengan siswa & 2 & 2 & 2.0 \\
\hline 4 & Kerjasama kelompok & 3 & 3 & 3.0 \\
\hline 5 & Aktivitas belajar siswa dalam diskusi kelompok & 2 & 2 & 2.0 \\
\hline 6 & Aktivitas siswa dalam melaksanakan pembelajaran & 4 & 3 & 3.5 \\
\hline 7 & Keterampilan siswa dalam menggunakan alat peraga & 3 & 2 & 2.5 \\
\hline 8 & Partisipasi siswa dalam menyimpulkan materi & 3 & 3 & 3.0 \\
\hline Jumlah & & \multicolumn{3}{|c|}{$\mathbf{2 1 , 5}$} \\
\hline Rata-rata & $\mathbf{3 9}$ \\
\hline Persentase & \multicolumn{3}{|c|}{ cukup } \\
\hline
\end{tabular}

Tabel 2 tentang aktivitas siswa menggunakan model pembelajaran TAI pada siklus I di atas dapat dijelaskan bahwa persentase yang didapat siklus ini telah berada pada kategori "Cukup" dengan persentase sebesar $67,19 \%$ hal ini menunjukkan aktivitas siswa belum sesuai dengan yang direncanakan dalam penelitian ini minimal $75 \%$.

Pengamatan atau observasi juga dilakukan terhadap kemampuan guru mengelola pembelajaran. Hasil observasi kemampuan guru mengelola pembelajaran yang diuraikan pada siklus I ini. Hasil observasi responden guru pertemuan I yaitu 65,5\% dan siklus I 70,5\% dengan kualifikasi nilai "cukup". Dari hasil kinerja guru pada siklus I dapat dilihat jelas bahwa model pembelajaran TAI belum terlaksana dengan baik, mka peneliti ini masih dilanjutkan ke siklus II, diharapkan pada siklus II guru PTK lebih ditingkatkan lagi kemampuannya dalam mengelola ruangan saat kegiatan belajar mengajar berlangsung.

Rata-rata pencapaian kinerja guru pada siklus I dapat dilihat pada Gambar 2.

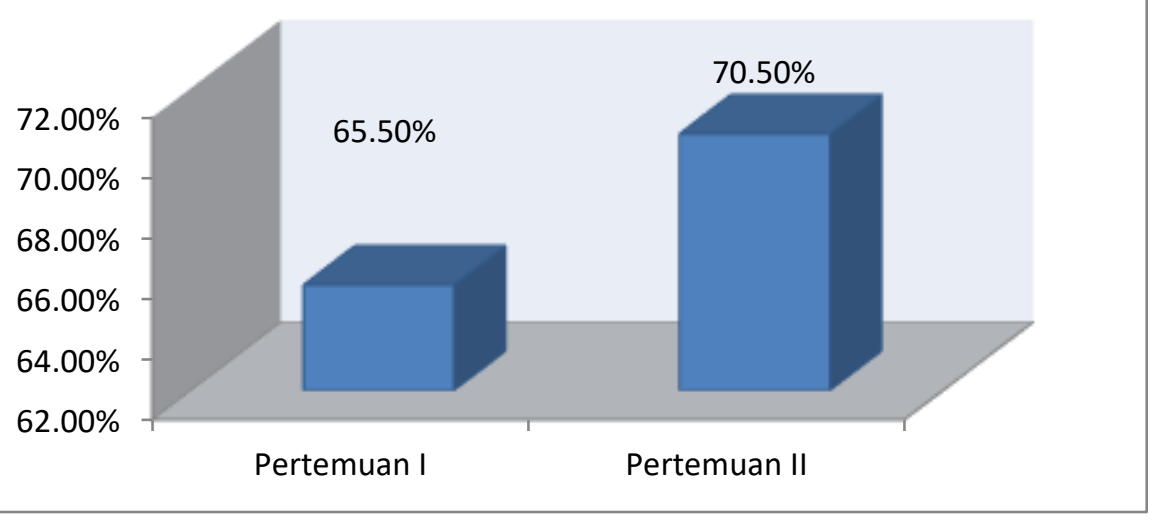

Gambar 2. Observasi Kinerja Guru Siklus I

Berdasarkan kriteria kemampuan guru mengelola pembelajaran melalui penerapan model pembelajaran TAI yang diuraikan pada siklus I, maka dengan melihat data pada tabel di atas dapat disimpulkan bahwa persentase yang diperoleh sebesar 70,50\% dengan kategori "Cukup" kemampuan guru mengelola pembelajaran masih kurang.

Hasil observasi pada siklus I, guru dan siswa telah melakukan kegiatan pembelajaran yang sesuai dengan model pembelajaran TAI namun masih dapat kekurangan-kekurangan. Dimana kekurangan itu pada yang berasal dari guru dan juga berasal dari siswa. Diantaranya sebagaimana siswa yang tidak memperhatikan penjelasan pada saat guru menyampaikan materi dan kekurangan yang berasal dari guru adalah belum terlaksananya semua komponen dalam skenario pembelajaran. Selain itu, pengetahuan awal siswa tentang materi yang akan dipelajari masih kurang. Menurut Slavin (2008:204) Model pembelajaran 
ISSN. 2621-9832

JURNAL MathEdu (Mathematic Education Journal) http://journal.ipts.ac.id/index.php/MathEdu Vol. 4 No. 2 Juli 2021

Team Assisted Individualization merupakan perpaduan antara pembelajaran kooperatif dan pengajaran individual. Model ini memperhatikan perbedaan pengetahuan awal tiap peserta didik untuk mencapai hasil belajar. Pembelajaran individual dipandang perlu diaplikasikan karena peserta didik memasuki kelas dengan pengetahuan, kemampuan, dan motivasi yang berbeda-beda.

Saat guru mempresentasikan materi pembelajaran, tentunya ada sebagian peserta didik yang tidak memiliki pengetahuan prasyarat untuk mempelajari materi tersebut. Ini tentu dapat menyebabkan peserta didik yang tidak memiliki pengetahuan prasyarat itu akan gagal mencapai tujuan pembelajaran yang diharapkan guru.

Pada tindakan siklus I ini penerapan model pembelajaran TAI dalam kegiatan belajar pembelajaran pada materi keliling dan luas bangun datar belum sempurna sesuai dengan yang diharapkan. Analisis terhadap observasi bahan untuk menentukan tindakan selanjutnya. Perbaikan yang dilakukan peneliti untuk memperbaiki proses belajar mengajar ayitu: 1) peneliti merancang perbaikan pembelajaran dengan memfokuskan pada hasil tes Hasil belajar siswa melalui model pembelajaran TAI; 2) Merancang kegiatan yang lebih melibatkan siswa dalam memahami materi pelajaran; 3) Berusaha untuk lebih dekat dengan siswa agar siswa tidak merasa canggung; 4) Hasil belajar siswa agar lebih berani bertanya dan menjawab soal-soal dengan kreatif; 5) Mengoptimalkan dan pemanfaatan waktu; 6) Membimbing siswa supaya mampu bekerja sama; 7) Menjelaskan materi dan lebih menghubungkannya dengan kehidupan sehari-hari agar lebih mudah pahami.

\subsection{Deskripsi Hasil Siklus II}

Siklus II merupakan tindakan lanjut refleksi pada siklus I. Bertolak dari pelaksanaan siklus I masih ada hal-hal yan belum dicapai, dikarenakan guru belum terbiasa menerangkan materi melalui model pembelajaran TAI. Siklus II dilaksanakan dua kali pertemuan sama dengan siklus I. Nilai rata-rata hasil belajar siswa dengan menggunakan model pembelajaran TAI pada siklus I sebesar 70, 43. Setelah dilakukan perbaikan pada siklus I, maka nilai rata-rata hasil belajar siswa menggunakan model pembelajaran TAI meningkat menjadi 81,25. Hal ini menunjukkan bahwa terjadi peningkatan hasil belajar siswa dengan menggunakan model pembelajaran TAI. Untuk memperjelas gambaran ketuntasan hasil belajar siswa pada siklus II dapat dilihat pada Gambar 3.

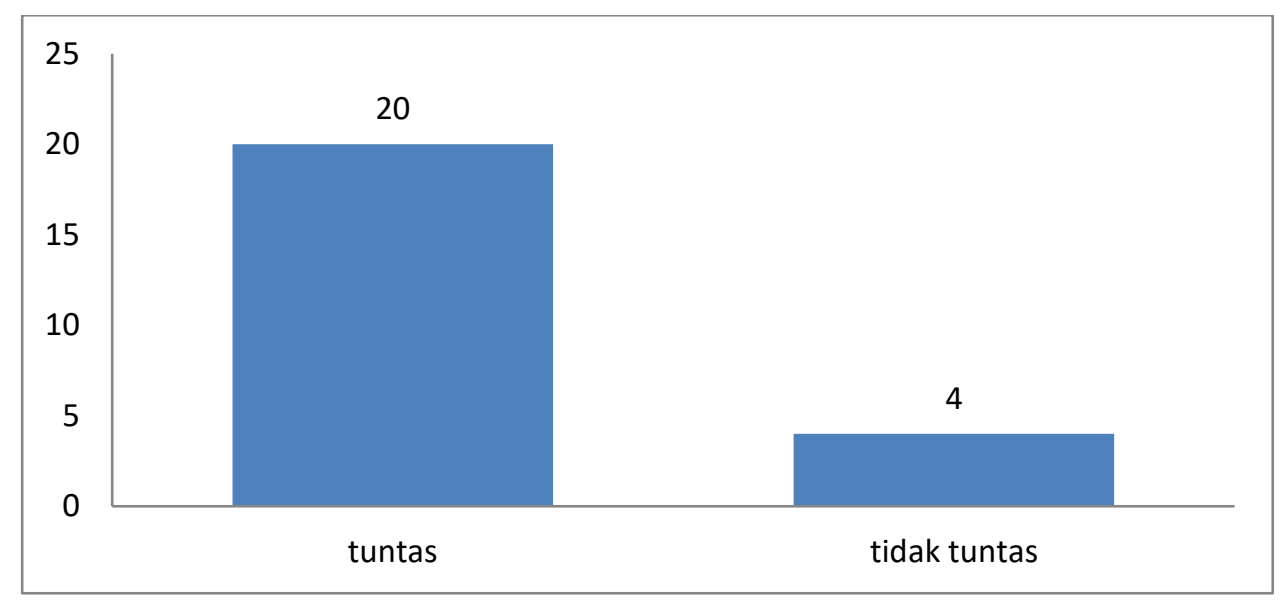

Gambar 3. Hasil Ketuntasan Hasil Belajar Siswa Siklus II

Dari 20 orang siswa yang mengikuti tes hasil belajar pada materi keliling dan luas bangun datar siswa siklus II, terdapat 20 orang atau $83 \%$ yang tuntas dan 4 orang atau $17 \%$ dinyatakan tidak tuntas. Berdasarkan hasil tes sikus II dapat dinyatakan bahwa telah memenuhi Kriteria Ketuntasan Minimal (KKM) $\geq 75$ dan telah terpenuhi indikator yang ditetapkan yaitu $75 \%$. Untuk itu penelitian dinyatakan telah memenuhi ketentuan yaitu rata-rata di atas Kriteria Ketuntasan Minimal (KKM) $\geq 75$, maka penelitian diberhentikan pada siklus siklus II.

Aktivitas belajar siswa dengan menggunakan model pembelajaran TAI pada siklus II mengalami peningkatan. Hal ini dapat dilihat pada Gambar 4. 


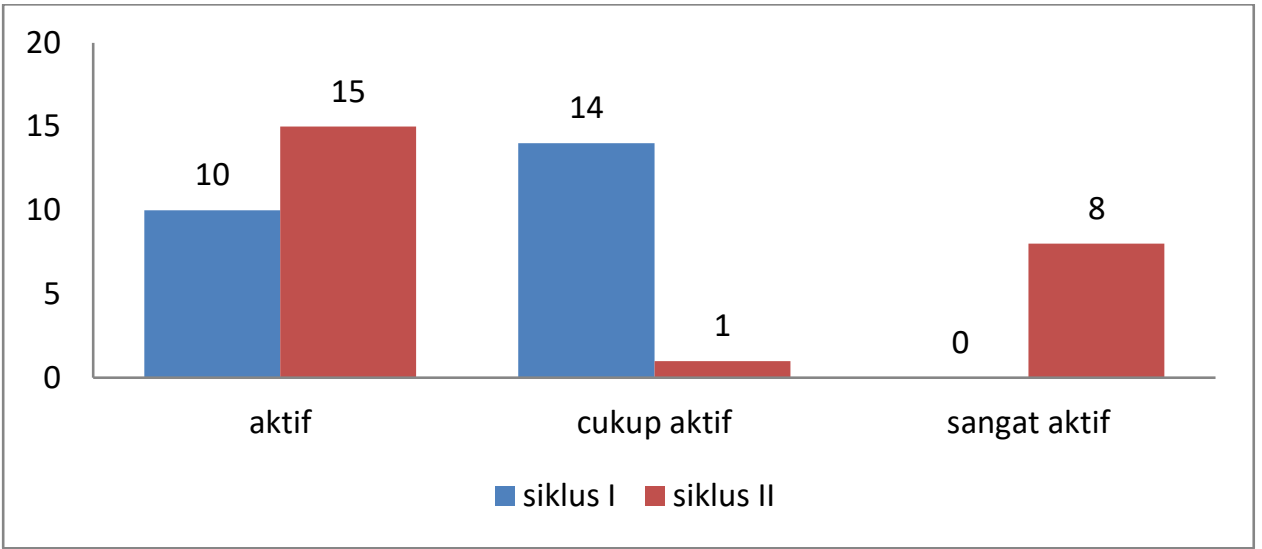

\section{Gambar 4. Gambaran Peningkatan Aktivitas Belajar Siswa Menggunakan Model Pembelajaran TAI Siklus II}

Dari 24 orang siswa yang mengikuti aktivitas belajar siswa pada siklus II diperoleh hasil bahwa jumlah siswa yang kriteria sangat aktif 8 orang, kriteria aktif mengikuti pembelajaran hanya 15 orang dan hanya 1 orang dengan kriteria cukup aktif, dari hasil yang diperoleh pada siklus II dapat dilihat bahwa hampir seluruh siswa telah aktif saat proses belajar pembelajaran.

Hasil Observasi Kinerja Guru dalam kegiatan mengajar pada siklus ke II ini, pertemuan I yaitu 72,5\% dan pertemuan ke II 82,5,5\% dengan kualifikasi nilai "cukup". Dari hasil kinerja guru pada siklus I dapat dilihat jelas bahwa model pembelajaran TAI belum terlaksana dengan baik. Maka peneliti ini masih dilanjutkan ke siklus II, diharapkan pada siklus II guru PTK lebih ditingkatkan lagi kemampuannya dalam mengelola ruangan saat kegiatan belajar mengajar berlangsung. Secara keseluruhan rata-rata pencapaian kinerja guru pada siklus I dapat dilihat pada Gambar 5.

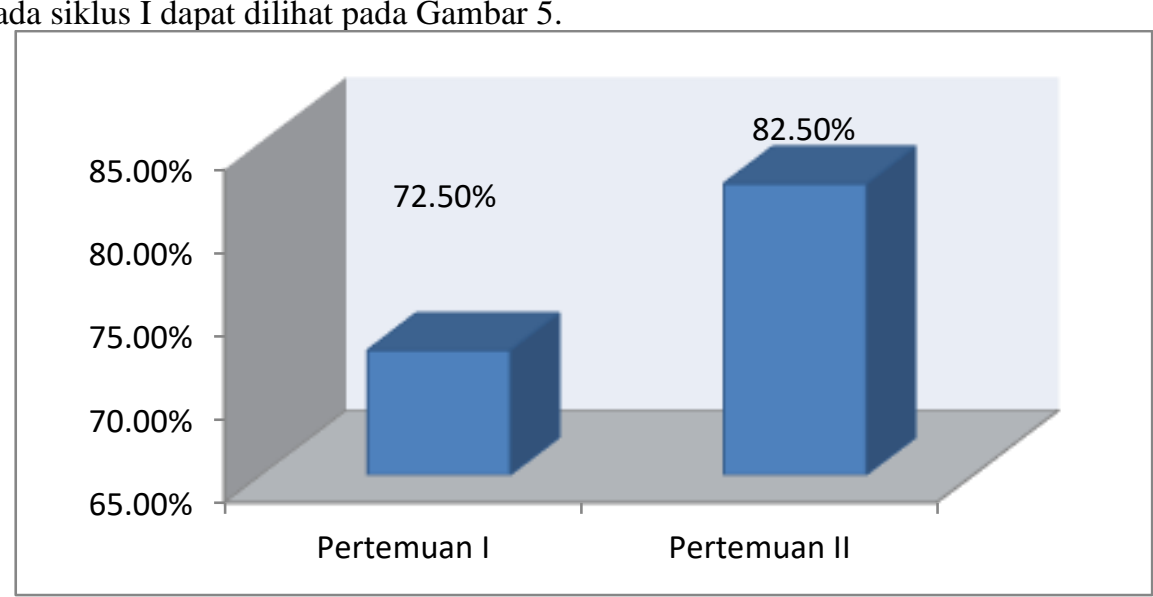

\section{Gambar 5. Observasi Kinerja Guru Siklus II}

Berdasarkan kriteria kemampuan guru mengelola pembelajaran yang diuraikan pada siklus II, maka dengan melihat data pada tabel di atas dapat disimpulkan bahwa persentase yang diperoleh sebesar 82,5\% dengan kategori "Amat Baik" kemampuan guru mengelola pembelajaran dan telah memenuhi kriteria $75 \%$ maka penelitian di berhentikan pada siklus II.

Guru yang bertindak sebagai observer mengenai siswa yang sedang mengikuti proses belajar pembelajaran di kelas IV SD Negeri 200304 Padangsidimpuan pada materikeliling dan luas bangun datar dengan model pembelajaran TAI untuk meningkatkan hasil belajar siswa. Hasil pengamatan terhadap aktivitas siswa dalam pembelajaran setiap pertemuan selama 2 kali tatap muka dinyatakan dengan persentasi. Hasil tersebut disajikan secara ringkas pada Tabel 3.

Tabel 3. Perolehan Skor Observasi Aktivitas Siswa Siklus II 
ISSN. 2621-9832

JURNAL MathEdu (Mathematic Education Journal) http://journal.ipts.ac.id/index.php/MathEdu Vol. 4 No. 2 Juli 2021

\begin{tabular}{|c|l|c|c|c|}
\hline \multirow{2}{*}{ No Indikator } & \multicolumn{1}{c|}{ Pertemuan } & \multirow{2}{*}{$\begin{array}{c}\text { Rata- } \\
\text { rata }\end{array}$} \\
\cline { 3 - 4 } & & I & II & \\
\hline 1 & $\begin{array}{l}\text { Antusiasme siswa dalam mengikuti kegiatan } \\
\text { pembelajaran }\end{array}$ & 3 & 4 & 3.5 \\
\hline 2 & Interaksi siswa dengan guru & 4 & 3 & 3.5 \\
\hline 3 & Interaksi siswa dengan siswa & 2 & 3 & 2.5 \\
\hline 4 & Kerjasama kelompok & 3 & 4 & 3.5 \\
\hline 5 & Aktivitas belajar siswa dalam diskusi kelompok & 3 & 3 & 3.0 \\
\hline 6 & Aktivitas siswa dalam melaksanakan pembelajaran & 4 & 3 & 3.5 \\
\hline 7 & Keterampilan siswa dalam menggunakan alat peraga & 3 & 4 & 3.5 \\
\hline 8 & Partisipasi siswa dalam menyimpulkan materi & 3 & 3 & 3.0 \\
\hline Jumlah & & \multicolumn{3}{|c|}{$\mathbf{2 6}$} \\
\hline Rata-rata & $\mathbf{8 1 , 2 5}$ \\
\hline Persentase & \multicolumn{3}{|c|}{ Amat Baik } \\
\hline
\end{tabular}

Siswa siklus II di atas dapat dijelaskan bahwa persentase yang didapat siklus ini telah berada pada kategori "Baik" dengan persentase sebesar $81,25 \%$ hal ini menunjukkan aktivitas siswa telah sesuai dengan yang direncanakan dalam penelitian ini minimal 75\%, maka penelitian diberhentikan pada siklus II.

Berdasarkan penjelasan-penjelasan di atas dapat disimpulkan bahwa pada siklus II ini hasil tes hasil belajar keliling dan luas bangun datar siswa telah meningkat dalam pembelajaran yang didukung oleh meningkatnya aktivitas guru dalam mempertahankan dan meningkatkan suasana pembelajaran yang mengarah pada model pembelajaran TAI untuk meningkatkan hasil belajar materi keliling dan luas bangun datar siswa. Keberhasilan pada siklus II ini dapat dilihat dari hasil observasi kinerja guru yang dilakukan pada setiap siklusnya dapat dilihat hasilnya yaitu siklus I pertemuan I memperoleh persentase $62,50 \%$ pertemuan II $67,5 \%$ dan pada siklus II guru lebih meningkat menjadi pertemuan I sebesar $72,50 \%$ dan pertemuan ke II sebesar 82,50\% dilihat dari indikator keberhasilan, maka guru mengalami peningkatan sebesar $15,50 \%$, dan hal ini telah mencapai indikator yang ditetapkan kemudian dilihat dari hasil observasi aktivitas siswa juga mengalami peningkatan, dimana pada siklus I memperoleh persentase sebesar 59,63\% dan siklus II sebesar $81,25 \%$ dilihat dari hasil tersebut data observasi aktivitas siswa mengalami peningkatan sebesar 14,06\%, Untuk lebih jelas dapat pada Gambar 5.

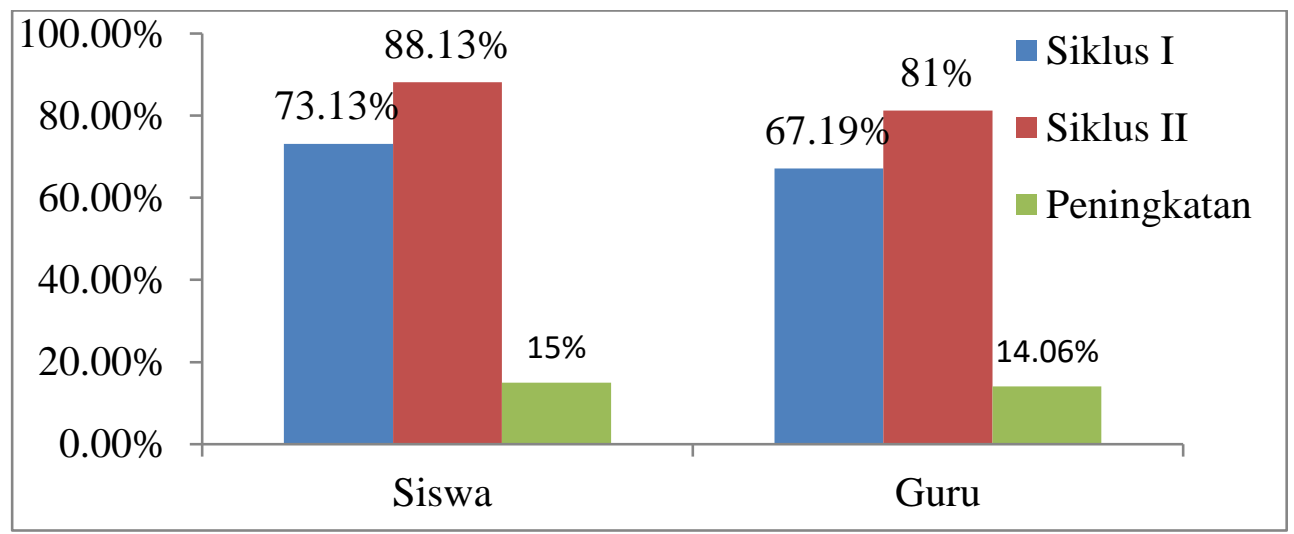

Gambar 5. Observasi Aktivitas Siswa dan Guru Siklus I dan Siklus II

Dalam proses belajar mengajar dengan menerapkan model pembelajaran TAI ini aktivitas belajar siswa menjadi bawah perhatian guru, berdasarkan observasi yang selalu dilakukan pada tiap pertemuannya maka pada siklus pertama hasil observasi untuk peningkatan hasil. Penelitian ini berakhir setelah selesai pelaksanaan siklus II, karena telah mencapai indikator kinerja yang telah ditetapkan, yaitu tolak ukur kinerja yang berkaitan dengan keberhasilan pelaksanaan pembelajaran yaitu minimal $75 \%$. Untuk itu penggunaan model pembelajaran TAI harus disesuaikan dengan sintaknya.

Menurut Suyitno (2007:10) tahapan rancangan penerapan model pembelajaran Team Accelerated Instruction (TAI) pada Tabel 5. 
JURNAL MathEdu (Mathematic Education Journal) http://journal.ipts.ac.id/index.php/MathEdu

Vol. 4 No. 2 Juli 2021

Tabel 5. Langkah-langkah Pembelajaran Model TAI

\begin{tabular}{|l|l|l|}
\hline No & $\begin{array}{l}\text { Langkah-langkah Model Team } \\
\text { Assisted Individualization }\end{array}$ & \multicolumn{1}{c|}{ Kegiatan Pembelajaran } \\
\hline 1 & Teams & $\begin{array}{l}\text { Pembentukan kelompok dimana peserta didik dibagi } \\
\text { menjadi kelompok kecil yang beranggotakan 4-5 orang }\end{array}$ \\
\hline 2 & Placement test & $\begin{array}{l}\text { Prosedur pembentukan kelompok berdasar pre tes } \\
\text { himpunan dan dirangking berdasarkan perolehan nilai }\end{array}$ \\
\hline 3 & Teaching Group & $\begin{array}{l}\text { 1. Pembagian handout untuk masing-masing. } \\
\text { 2. Penjelasan secara singkat pokok materi yang akan } \\
\text { dibahas pada pertemuan itu oleh guru. }\end{array}$ \\
\hline 4 & Student Creative & $\begin{array}{l}\text { Peserta didik belajar secara individu materi yang terdapat } \\
\text { pada handout dan mengerjakan 5 soal-soal. }\end{array}$ \\
\hline 5 & Team Study & $\begin{array}{l}\text { Peserta didik berdiskusi tentang materi dan mengoreksi } \\
\text { jawaban LKS dengan teman satu kelompok. }\end{array}$ \\
\hline 6 & Whole-Class Units & $\begin{array}{l}\text { 3. Perwakilan kelompok maju untuk mempresentasikan } \\
\text { hasil kerja kelompok. } \\
\text { 4. Kelompok lain memberikan tanggapan pertanyaan. }\end{array}$ \\
& & $\begin{array}{l}\text { Evaluasi hasil diskusi dan penyempurnan jawaban } \\
\text { peserta didikoleh guru. }\end{array}$ \\
\hline 7 & Facts test & $\begin{array}{l}\text { Pelaksanaan tes akhir dan peserta didik mengerjakannya } \\
\text { secara individu }\end{array}$ \\
\hline Team scores and team & $\begin{array}{l}\text { Pengumuman skor tiap kelompok serta penetapan dan } \\
\text { pemberian penghargaan bagi kelompok super, kelompok } \\
\text { hebat, dan kelompok baik }\end{array}$ \\
\hline
\end{tabular}

\section{KESIMPULAN}

4.1. Kesimpulan

Berdasarkan hasil penelitian tindakan kelas ini diperoleh kesimpulan sebagai berikut:

1. Hasil belajar belajar siswa mengalami peningkatan melalui model pembelajaran TAI di kelas IV SD Negeri 200304 Padangsidimpuan, yang mana dapat dibuktikan pada siklus I memperoleh persentase sebesar 54\%, pada siklus II adalah persentase sebesar $83 \%$, dari siklus I ke siklus II mengalami peningkatan sebesar $29 \%$.

2. Terjadinya Peningkatan kinerja guru melalui model pembelajaran TAI di kelas IV SD Negeri 200304 Padangsidimpuan, yang mana dapat dilihat pada persentase observasi responden guru pada siklus I sebesar 67,50\% dengan kategori "Cukup" dan siklus II 82,50\% dengan kategori "Baik", dari siklus I ke siklus II mengalami peningkatan sebesar 15,0\%.

3. Terjadinya peningkatan aktivitas belajar siswa melalui model pembelajaran Team Accelerated Instruction (TAI) dari siklus I ke siklus II mengalami peningkatan sebesar 48,49\% di kelas IV SD Negeri 200304 Padangsidimpuan, yang mana dapat dilihat pada persentase observasi aktivitas siswa pada siklus I sebesar 67,19\% dengan kategori "Cukup" dan siklus II 81,25\% dengan kategori "Baik”, dari siklus I ke siklus II mengalami peningkatan sebesar 14,06\%.

\subsection{Saran}

Berdasarkan kesimpulan yang telah dikemukakan, maka akan diberikan beberapa saran yang kiranya dapat bermanfaat untuk meningkatkan mutu pendidikan di kelas IV SD Negeri 200304 Padangsidimpuan sebagai berikut:

1. Untuk mengajarkan materi pokok keliling dan luas bangun datar di kelas IV SD dapat menggunakan model pembelajaran TAI dengan sintak yaitu: Teams, Test, Teaching Group, Student Creative, Team Study, Whole-Class Units, Facts Test, Team Scores and Team Recognition karena dapat meningkat hasil belajar siswa khususnya di kelas IV SD Negeri 200304 Padangsidimpuan .

2. Untuk peneliti selanjutnya yang memiliki kesamaan dengan penelitian ini, maka perlu merancang lembar kerja peserta didik dengan menggunakan sintak model pembelajaran TAI

3. Untuk meningkatkan rasa percaya diri siswa dalam penggunaan model pembelajaran TAI harus menggunakan pertanyaan yang bervariasi agar siswa dapat mengeluarkan pendapat di depan kelas dengan rasa percaya diri yang tinggi. 
JURNAL MathEdu (Mathematic Education Journal) http://journal.ipts.ac.id/index.php/MathEdu

\section{REFERENSI}

Fikrie, 2012. Strategi dan Model Pembelajaran. Jakarta : Indeks

Handayani, Ruli, 2012. Dengan judul Penerapan Model Pembelajaran Kooperatif Tipe TAI (Team Accelerated Instruction) Untuk Peningkatan Hasil Belajar Matematika Siswa Kelas IVIII E SMP Negeri 1 Kec. Siman Ponorogo Tahun Pelajaran 2011/2012.

Karim, 2017. Pembelajaran Abad 21. Yogyakarta : Gava Media.

Slavin, 2008. Cooperative Learning (Teori, Riset, Praktik). Bandung : Media Nusa.

Suyitno, 2007. Cooperative Learning Analisis Model. Pembelajaran. Yogyakarta : Media Ar-Ruzz. 